\title{
Factors Influence Women Teachers' Perception of Glass Ceiling Syndrome
}

\author{
Kadın Ö̆̆retmenlerin Cam Tavan Sendromu Algısını Etkileyen Faktörler
}

\section{Rabia BATO ÇİZEL ${ }^{*}$ Beykan ÇİZEL ${ }^{* *}$}

\begin{abstract}
This study empirically investigated the influence of learned helplessness and selected sociodemographic variables on women teachers' perception of glass ceiling syndromes propensity. A research study was conducted with the women teachers working in college in the city of Antalya for the purpose of identifying the significant predicators. The results from the binary logistic regression analysis reveal that child possession and learned helplessness are the main factors affecting women teachers' perception of the glass ceiling syndrome in their working environment. This shows that in order to understand women teachers' perception of the glass ceiling syndrome, one should take into account not only sociodemographic, but also psychological factors such as learned helplessness.
\end{abstract}

Keywords: Glass ceiling Syndrome, learned helplessness, women teachers, Logistic Regression

Öz: Bu çalışmada psikolojik bir değişken olan öğrenilmiş çaresizliğin ve seçilen sosyo-demografik değişkenlerin kadın öğretmenlerin cam tavan sendromu algısı üzerindeki etkisi görgül olarak incelenmiştir. Çalışma grubu, Antalya ilindeki özel okullarda çalışan kadın öğretmenlerden seçilmiş ve veriler anket yöntemi ile toplanmıştır. Uygulanan Lojistik regresyon analizi sonuçları öğrenilmiş çaresizliğin ve çocuk sahibi olmanın kadın öğretmenlerin işyerinde yaşadıkları cam tavan sendromu üzerinde etkisinin olabileceğini ortaya koymuştur. Araştırma sonuçları kadın öğretmenlerin işyerinde yaşadıkları cam tavan sendromunun incelenmesinde ve anlaşılmasında sosyo-demografik değişkenlerin yanında öğrenilmiş çaresizlik gibi psikolojik değişkenlerin de incelenmesini gerektiğini göstermesi açısından önemlidir.

Anahtar sözcükler: Cam Tavan Sendromu, Öğrenilmiş Çaresizlik, Kadın Öğretmenler, Lojistik Regresyon

\section{Introduction}

While the average stay of women's labor force participation rate is $61.8 \%$ in OECD countries, this ratio is only $28.8 \%$ in Turkey. According to the Turkish Statistic Institution, the noninstitutional female population in Turkey is around 37.2 million as of October 2012. Moreover, the numbers of women aged over 15 years were determined as 27.9 million. In parallel with these ratios, number of women working is only 7.6 million (Aş1k, 2013, 1). According to World Bank classifications, Turkey with the lowest women labor force participation rate was in the same group of developing countries in Europe and Central Asia (Can, \& Özer, 2012). Women

\footnotetext{
* Doç. Dr., Akdeniz Üniversitesi, İktisadi ve İdari Bilimler Fakültesi, Çalışma Ekonomisi ve Endüstri İlişkileri Bölümü, Antalya, rabiacizel@akdeniz.edu.tr

** Doç. Dr., Akdeniz Üniversitesi, Turizm Fakültesi, Turizm İşletmeciliği Bölümü, Antalya, beykan@akdeniz.edu.tr This article was presented at the Global Interdisciplinary Business-Economics Advancement Conference (GIBA 2014), May 15-18, 2014, in Clearwater Beach, Tampa, Florida, USA.
} 
have been trying to get out of the traditional line in every sphere of life in this country. Nevertheless, women cannot be adequately represented especially in leadership positions in every sector.

The teaching profession is considered to be a female profession in Turkey. Although the number of female teachers is greater than the number of male teachers, there is known to be a cliff between the number of female and male managers. Women are disappointed when they cannot get promotion to managerial positions, As a result, women have to give up efforts towards career progression and leave their jobs. It is pretty hard to overcome barriers which are termed the glass ceiling for women. Consequently the number of women who can gain access to top management position is very limited. The large majority of the remaining working women give up their efforts for promotion. In other words, women feel helpless and suffer from learned helplessness syndrome because they believe they will never be successful. This study aims to empirically investigate the influences of learned helplessness and selected socio-demographic variables upon women teachers' perception of glass ceiling syndromes.

A glass ceiling is a political term used to describe "the unseen, yet unbreakable barrier that keeps minorities and women from rising to the upper rungs of the corporate ladder, regardless of their qualifications or achievements. The glass ceiling metaphor has often been used to describe invisible barriers ("glass") through which women can see elite positions but cannot reach them ("ceiling"). These barriers prevent large numbers of women and ethnic minorities from obtaining and securing the most powerful, prestigious, and highest-paying jobs in the workforce (US Federal Glass Ceiling Commission Report, 1995).

It can be noted that the proportion of women in lower and mid-level management positions has increased dramatically, while the proportion of women reaching top management positions or climbing up the corporate ladder has remained relatively small. According to Meyerson and Fletcher (2000), despite the increased numbers of women both participating in the workforce and achieving management positions, the 'glass ceiling' still exists. Women are denied only because they are women (Şimşek, et alii, 2007). In summary, all these indicate the glass ceiling is both visible and invisible obstacle which separates the professional and organizational hierarchical level for females from males.

Seligman (1976) introduced the Learned Helplessness Theory following many years of animal and human experimentation. According to this theory, learned helplessness occurs initially when an individual perceives a situation as an unfavorable stress or challenge. The individual therefore identifies potential actions to manipulate the situation to make it less challenging, less stressful, and/or more favorable. According to the Learned Helplessness Theory, an individual moves from situational perception to learning behaviors and the outcomes are independent of one another as surrounding situations are unable to be influenced by personal actions.

This theory may influence the female teachers' perception of glass ceiling syndromes. According to this theory, if a person is prevented from behaving freely, they may then become more determined to behave in the way in which they want. However, if they are repeatedly prevented from doing so, they may perceive the desired behavior to be beyond their own control. As a result, they may either give up and/or lose confidence in trying to achieve it, and consequently they experience helplessness, even if these circumstances change, and so enable them to subsequently behave in the manner to which they desired in the first place. In such cases, the individual has learned to behave helplessly irrespective of whether the opportunity is restored to them to help themselves, by avoiding unpleasant or harmful circumstances to which they have been subjected. Learned helplessness may arise in everyday situations in which the 
female teacher feels or actually has no control over what happens to themselves regarding their perception of the glass ceiling syndrome.

Repeated unsuccessful experiences in the past will affect the performance of employees and this situation may lead to learned helplessness (Kümbül-Güler, 2012, 500). From the perspective of psychology, there may be serious consequences of learned helplessness such as alienation, abandonment of job due to dissatisfaction, burnout and absenteeism (Tayfur, 2012). Qutaiba (2011) revealed that there is a correlation between learned helplessness and the loyalty of teachers in schools.

\section{Aim and Method of the Study}

This study aims to empirically investigate the influences of learned helplessness and selected socio-demographic variables on women teachers' perception of glass ceiling syndromes. A research study was conducted with women teachers working in college in the city of Antalya. To collect data for this study, a questionnaire was conducted to research group was chosen by convenience sampling method. A self administered questionnaire was distributed to teachers. The purpose of the survey was explained to the participants and only volunteers were recruited for the study. The data collection was conducted from June to May in 2014. 83 questionnaires were obtained after eliminating the incomplete questionnaires.

The survey instrument consist of two sections. First section includes demographic questions and a binary categorical scale is pertinent to the female teachers' perception of glass ceiling syndrome. Section 2 deals with the measurement of the female teachers' perception of learned helpless with 11 items, five point Likert scale anchored by "strongly disagree $(=1)$ to "strongly agree ( $5=$ ) was used in the scale. The data analysis was carried out in three main stages. First, descriptive statistics analyzed the profiles of the respondents. Second, a principal factor analysis with a varimax rotation method was conducted on the learned helpless scale for data reduction purposes. Third, a binary logistic regression was employed to investigate the predictive utility of selected demographic variables and learned helplessness the female teacher's perception of glass ceiling syndrome. This study specifies the teachers' perception of glass ceiling syndrome ( $0=$ no, $1=$ yes) as the dependent variable for the logistic regression, while teachers' perception of learned helplessness and demographic variables are the independent variables.

The underlying dimensions of the 11 learned helplessness items were assessed using principal component analysis (PCA). A varimax rotation was followed. Principal component analysis is a standard statistical procedure that identifies a hidden structure in a set of variables. It is appropriate for large numbers of items and large sample. A check on the adequacy of the sample size was made using the Keiser-Meyer-Olkin (KMO) measurement of sampling adequacy. In this study the value was 0.84 , indicating a very satisfactory sample size. When Eigen values greater than 1 were considered, the procedure produced 2 factors. Eigen values are a measure of the coherence of the factor and depend on the number of items loading or defining the underlying dimension of interest.

Usually when eigen values are 1 or more, the underlying dimension in the data is considered to represent a strand of meaning worthy of further consideration. Only items where the factor loadings were above 0.40 were used to explain the factor (Nunnally, 1978). The percentage of variance explained by this solution was $63,4 \%$. Cronbach's coefficient alpha was used to measure the internal consistency among the items. Hair, et alii (1999) report that this is the most generally used reliability measure to estimate the degree to which the items on a measure are representative of the domain of the construct being measured. The criteria of 0.70 for the coefficient alpha is 
usually considered reliable. Both two factors resulted in a Cronbach's coefficient alpha score above 0.70 , which indicates strong consistency among the items in each factor. The results are shown in Table 1.

Table 1. Factor Analysis of Learned Helplessness

\begin{tabular}{|c|c|c|}
\hline Factors & Items & $\begin{array}{l}\text { Factor } \\
\text { loadings }\end{array}$ \\
\hline \multirow{6}{*}{$\begin{array}{l}\text { Learned } \\
\text { helplessness } \\
(38,5) \mathrm{a} \\
(\boldsymbol{\alpha}=, 93) \mathrm{b}\end{array}$} & $\begin{array}{l}\text { No matter how much energy I put into a task, I feel I have no } \\
\text { control over the outcome. }\end{array}$ & ,903 \\
\hline & I do not try a new task if I have failed similar tasks in the past. & ,922 \\
\hline & $\begin{array}{l}\text { No matter how hard I try, things never seem to work out the way I } \\
\text { want them to. }\end{array}$ & 871 \\
\hline & I don’t place myself in situations in which I cannot. & ,896 \\
\hline & I do not try a new task if I have failed similar tasks in the past. & 828 \\
\hline & I am unable to reach my goals in life. & ,785 \\
\hline \multirow{6}{*}{$\begin{array}{l}\text { Learned inability } \\
(24,9) \mathrm{a} \\
(\boldsymbol{\alpha}=, 93) \mathrm{b}\end{array}$} & I do not have the ability to solve most of life's problems. & ,727 \\
\hline & $\begin{array}{l}\text { I feel that my own inability to solve problems is the cause of my } \\
\text { failures. }\end{array}$ & ,739 \\
\hline & I feel that my success reflects chance, not my ability. & 623 \\
\hline & $\begin{array}{l}\text { My behavior does not seem to influence the success of a work } \\
\text { group. }\end{array}$ & ,695 \\
\hline & I cannot find solutions to difficult problems. & 614 \\
\hline & I am unsuccessful at most tasks I try. & ,761 \\
\hline
\end{tabular}

Kaiser-Meyer-Olkin measure of sampling adequacy: 0.84

$67.9 \%$ of variance explained; motive items with factor loading $<0.40$ is discarded $a=$ Variance explained, $\mathrm{b}=$ Cronbach's alpha reliability coefficient

\section{Results}

Table 2 shows the demographic profile of respondents. Among the 83 usable questionnaires, the dominant majority are married. In all, 90\% hold a undergraduate degree, slightly over half of the respondents have no child.

Table 2. Respondents' Profile ( $\mathrm{N}=83$ )

\begin{tabular}{|l|c|c|}
\hline Demographic variables & Frequency & Percentage \\
\hline Age & 10 & 12.0 \\
\hline $20-29$ & 35 & 42.2 \\
\hline $30-39$ & 18 & 21.7 \\
\hline $40-49$ & 20 & 24.1 \\
$49-$ older & 75 & 90.0 \\
\hline Education & 8 & 10.0 \\
\hline Undergraduate & 23 & 72.0 \\
\hline Graduate & \multicolumn{2}{|l}{} \\
\hline Marital Status & \multicolumn{2}{|l|}{} \\
\hline Single & \multicolumn{2}{|l|}{} \\
\hline
\end{tabular}




\begin{tabular}{|l|l|l|}
\hline Couple & 60 & 28.0 \\
Child Possession & 38 & 45.7 \\
Yes & 45 & 54.3 \\
No & & \\
\hline
\end{tabular}

\section{Logistic Regression Analysis}

A logistic regression is a suitable technique to predict the likelihood of an event to occur and uses a dichotomous dependent variable. Likewise, it can accommodate independent variables that are measured on either a continuous or categorical scale. In this study, the perceived glass ceiling syndrome is expressed as a discrete variable $\mathrm{Y}$ with a value 1 if the respondent is likely to perceive glass ceiling syndrome, and a 0 if not - that is:

$$
\mathrm{Y}_{\mathrm{i}}^{*}=\alpha \mathrm{Z}+\beta \mathrm{i},
$$

Where $\mathrm{Yi}^{*}$ is an unobservable variable reflecting the likelihood of perceived glass ceiling syndrome. The observed counterpart of $\mathrm{Y} i *$ is $\mathrm{Y} i$ with an observed value.

$$
\begin{array}{ll}
\mathrm{Y}=0 & \mathrm{Y}_{\mathrm{i}}^{*} \leq 0, \\
\mathrm{Y}=1 & \mathrm{Y}_{\mathrm{i}}^{*} \geq 0,
\end{array}
$$

Among the 83 usable questionnaires, 38 teachers reported that they perceived glass ceiling syndrome (i.e. $\mathrm{Y}=1$ ), while 45 teachers did not perceive glass ceiling syndrome. Selected demographic variables (marital status, child possession) and two factors of perceived learned helplessness are specified as the dependent variables. The factors of perceived learned helplessness are continuous measures while the demographic variables are discrete measures. For simplicity, the demographics were converted to dichotomous measures (as shown in Table 3) before the logistic regression analysis.

Table 3. Definitions of Dichotomous Demographic Variables.

\begin{tabular}{|l|l|}
\hline Variables & Dichotomous value \\
\hline Marital status & $\begin{array}{l}\text { couple }=1 \\
\text { single }=0\end{array}$ \\
Child possession & $\begin{array}{l}\text { Yes }=1 \\
\text { No }=0\end{array}$ \\
\hline
\end{tabular}

Table 4 shows the results of the logistic regression. To assess the model's goodness of fit, the chi-square value and the Hosmer and Lemeshow goodness-of-fit index are computed. As shown in Table 4, the model chi-square is significant (i.e. $\chi 2=48.426$, d.f $.=2, p=0.000$ ), indicating that the classification of teachers into perceived glass ceiling syndromes and those that did not perceive itcould be predicted from the study's independent variables. In addition, the Hosmer and Lemeshow goodness-of-fit index is 20.005 (d.f. $=8, p=0.010$ ), meaning that the model fits quite well.

The second column of Table 4 shows the logit estimates of the parameter $\beta$ for all independent variables. The fifth column shows the significant $p$-value for these sample statistics. Two learned helplessness factor - namely, learned inability and learned helplessness- are significant at $\mathrm{p}<.05$. Here, the $\beta$ s of learned inability (1.990) and learned helplessness (1.824) are positive. This implies that the more learned helplessness teachers perceive; the more likely they are to perceive glass ceiling syndromes. The odds ratios of both learned inability and learned helplessness are greater than 1 , revealing that they predict which type of respondent is 
more likely to perceive glass ceiling syndromes. 1 . The odds of propensity to perceive glass ceiling syndromes, if the respondent has a child. Regarding the demographic variables, only child possession is significant at $\mathrm{p}<.01$. The $\beta$ (3.706) of this variable is positive and its odds ratio is greater than.

Table 4. Result of Binary Logistic Regression (Dependent variable: glass ceiling syndromes, $n=83$ ).

\begin{tabular}{|l|c|c|c|c|c|}
\hline Variables (1) & $\boldsymbol{\beta ( 2 )}$ & SE (3) & WALD (4) & Sig. (5) & $\operatorname{Exp(\beta )~(6)~}$ \\
\hline Learned inability & $1.990^{*}$ & 0.957 & 4.320 & 0.038 & 7.316 \\
Learned Helplessness & $1.824^{*}$ & 0.739 & 6.098 & 0.014 & 6.196 \\
\hline Child possession & $3.706^{* *}$ & 0.907 & 16.692 & 0.000 & 10.698 \\
\hline Marital status &,- 010 & 0.943 & 0.000 & 0.992 & 0.990 \\
\hline Constant & -17.584 & 4.822 & 13.300 & 0.000 & 0.000 \\
\hline
\end{tabular}
Log-Likelihood = -66.045
Hosmer-Lemeshow: 20.005 (d.f.=8, p = 0.010)
Notes: (a). 1, marital status (couple) = 1, child possession (possess) = 1 |(b). **: p < 0.01, *: p < 0.05.

\section{Conclusion}

This study has empirically investigated the influences of learned helplessness and selected socio-demographic variables upon women teachers' perception of glass ceiling syndromes propensity. Research was conducted with women teachers working in college in the city of Antalya for the purpose of identifying the significant predicators.

The results from the binary logistic regression analysis reveal that child possession and learned helplessness are the main factors affecting women teachers' perception of the glass ceiling syndrome in their working environment. This shows that in order to understand women teachers' perception of the glass ceiling syndrome, one should take into account not only sociodemographic, but also psychological factors such as learned helplessness.

George (2005) emphasized that having children brings a lot of responsibilities to family life. This may be the reason why many women decide to leave their careers prematurely so as to raise adequately their children. For this reason, employers occasionally hesitate to promote women because they are afraid that women will place their families before employment. Family responsibility refers to instrumental activities relating to child upbringing, providing goods and support services for the family. Family responsibilities played a major role in whether or not the women had accepted the jobs.

The findings herein are also limited to the locational scope of this study. The sample of this study was only obtained from women teachers working in private schools. Last but not least, empirical data by employing a probability sampling method rather than a convenience sampling method can improve the representativeness of research objects. 


\section{REFERENCES}

Aşık, G., A. (2013). “Türkiye'yi Kadınlar Büyütebilir mi?”. Türkiye Ekonomi Politikaları Araştırma Vakfi, Şubat: 1-6.

Can, N., \& Özer, M. (2012). “Türkiye'de İşgücü Piyasası”. Attlım Üniversitesi Siyasi ve Ekonomik Araşttrmalar Laboratuvarı, Aralık, 1-4.

"Federal Glass Ceiling Commission. Solid Investments: Making Full Use of the Nation's Human Capital”. Washington, D. C.: U.S. Department of Labor, November 1995, 4.

Kümbül-Güler, B. (2012). "Bir Depresyon Teorisi Olarak Öğrenilmiş Çaresizliğin Çalışma Hayatındaki Yansıması”. Eds. Keser, A., Yılmaz, G., \& Yürür, S. Çalışma Yaşamında Davranış İ̧̧inde, 473-516.

Meyerson, D., E., \& Fletcher, J., K. (2000). “A Modest Manifesto for Shattering the Glass Ceiling”. Harvard Business Review, Jan-Feb, 126-136.

Nunnally, J., C. (1978). Psychometric theory. New York: McGraw-Hill.

Qutaiba, A. (2011). "The Relationship Between the Level of School-Involvement and Learned Helplessness Among Special-Education Teachers in the Arab Sector”. Australian Journal of Teacher Education, 36 (2), 1-15.

Seligman, M., E., P. (1972). “Learned Helplessness”. Annual Review of Medicine, 23, 407-412.

Şimşek, M., Ş., Çelik, A., \& Akatay, A. (2007). Kariyer Yönetimi ve İnsan Kaynakları Yönetimi Uygulamaları. Gazi Kitabevi. Ankara.

Tayfur, Ö. (2012). "The Antecedents and Consequences of Learned Helplessness in Work Life". Information Management and Business Review, 4 (7), 417-427. 
